\title{
Multilevel Analysis on the Ecological Effect of School on the Risk of Anemia among Female High School Students in Klaten Central Java
}

\author{
Nurmala Dewayanti'), Endang Sutisna Sulaeman², Bhisma Murti' ${ }^{\text {) }}$ \\ 1)Masters Program in Public Health, Universitas Sebelas Maret \\ 2)Faculty of Medicine, Universitas Sebelas Maret
}

Background: Anemia is a major nutritional problem worldwide. In 2018, at least 1.62 billion people were affected by anemia, and $33 \%$ were school children. Anemia in female adolescents contributes to high rates of maternal and infant mortality. This study aims to analyze the determinants of anemia among female adolescent at the individual level and at the school level.

Subjects and Method: This study used a cross sectional research design. The study was conducted in Klaten Regency in February 2020. Sampling used was probability sampling with a total of 200 female adolescents aged 15 to 19 years old. The independent variables include knowledge, family economy, menstrual pattern, consumption of blood supplement tablets, and nutritional status. The dependent variable is anemia. Data were collected by using the Easy Touch brand hemoglobinometer, weighing scale, microtoice and questionnaire. Data were analyzed using multilevel multiple logistic regression with a stata of 13 .

Results: The results of this study indicated that good knowledge $(b=-2.29 ; 95 \% \mathrm{CI}=-4.23$ to $-0.32 ; \mathrm{p}=0.022$ ), family economy $\geq \mathrm{Rp}$ $1,947,821(b=-2.73 ; 95 \% \mathrm{CI}=-4.58$ to $-0.75 ; \mathrm{p}=$
0.006), regular menstrual patterns $(b=-2.29$; $95 \% \mathrm{CI}=-4.58$ to $-0.75 ; \mathrm{p}=0.001)$, blood supplement consumption $(\mathrm{b}=-3.22 ; 95 \% \mathrm{CI}=-$ 8.96 to $-2.17 ; \mathrm{p}=0.001$ ), normal nutritional status $(b=-3.36 ; 95 \% \mathrm{CI}=-6.65$ to $-1.74 ; \mathrm{p}=$ o.001) reduce the incidence of anemia in adolescents. Variations at the school level indicate a contextual influence on the incidence of anemia in adolescents (ICC $=59.36 \%)$.

Conclusion: There was a statistically significant influence of knowledge, family economy, menstrual patterns, blood supplement consumption and nutritional status on the incidence of anemia in adolescents. Variations at the level of school indicated that there was a contextual influence on the incidence of anemia in adolescents.

Keywords: Multilevel, Anemia, Adolescents, School

\section{Correspondence:}

Nurmala Dewayanti. Masters Program in Public Health, Universitas Sebelas Maret. Jl. Ir. Sutami 36A, Surakarta 57126, Central Java. Email: nurmaladewayanti@gmail.com. Mobile: +6287734875004 .

\section{Cite this as:}

Dewayanti N, Sulaeman ES, Murti B (2021). Multilevel Analysis on the Ecological Effect of School on the Risk of Anemia among Female High School Students in Klaten Central Java. J Matern Child Health. 06(01): 1-14. https://doi.org/10.26911/thejmch.2021.06.01.01. Journal of Maternal and Child Health is licensed under a Creative Commons Attribution-NonCommercial-ShareAlike 4.0 International License.

\section{BACKGROUND}

Anemia is a major nutritional problem worldwide. Anemia in Indonesia is also a major nutritional problem. This makes anemia a serious public health problem around the world. Anemia can be caused by infec- tious diseases, insufficient nutritional intake, blood loss (menstruation) and knowledge. Anemia can have a big impact on the health and well-being of women, because it can increase the risk of being bad 
for pregnant women and newborns (Suryani et al., 2015).

As a developing country, the incidence of anemia in Indonesia is still quite high (National Institute of Health Research and Development, 2013). In 2018, at least 1.62 billion people were affected by anemia, of which $33 \%$ were school children. The prevalence of anemia in the world according to WHO is still around $40 \%$ to $88 \%$. About 370 million women in various developing countries suffer from iron deficiency anemia, $41 \%$ of which are non-pregnant women. The prevalence of anemia in Indonesia is still quite high (Fakhidah et al., 2016). Based on Basic Health Research (2018), there was an increase in the prevalence of anemia in pregnant women from 2013, which was $37.1 \%$ to $48.9 \%$ in 2018 with the proportion of anemia in the age group 15 to 24 years and 25 to 34 years. The incidence of anemia in Central Java in 2013 reached $57.1 \%$. The prevalence of anemia in women is relatively higher $(23.90 \%)$ than men (18.40\%).

Anemia is more common in girls than boys. This is because young women lose iron $(\mathrm{Fe})$ during menstruation, so they need more iron intake. Anemia in young women contributes to high rates of maternal and infant mortality.

Adolescence is a period of growth and development, both physically, mentally, and in activities, so that the need for food containing nutrients becomes quite large. Many young women experience lack of nutrients in their daily food consumption. In adolescence, changes occur in a person's physical, biological, and psychological and occur continuously during adolescence. An imbalance between intake and nutritional needs results in nutritional problems, both under nutrition and over nutrition (Briawan, 2013).
The important thing in controlling anemia in pregnant women is to ensure that iron needs in adolescents are fulfilled. There are several factors that can cause anemia, including nutritional status, menstruation, and socioeconomic conditions. Simamora et al. (2018) added the level of education is one of the fundamental causes that can lead to anemia. This is because the level of education affects the level of knowledge on nutritional intake that must be fulfilled every day. A good understanding of adequate nutritional intake will have an impact on a good diet so that it can prevent anemia in the community, especially in female adolescent who are prone to anemia.

School contextual factors can affect adolescent anemia such as sanitation of the school environment. There are several factors related to environmental health and sanitation, one of which is worm infection. Worm infection greatly affects the incidence of anemia in school age children.

Anemia treatment is needed in policy makers to invest as a means of promoting development, economic growth, health, wealth and welfare of a country. Researchers are interested in conducting study related to the effect of school context on the incidence of anemia in adolescents aged 15 to 19 years old in Klaten Regency. This study is expected to describe the benefits, so that efforts to prevent anemia can be carried out.

\section{SUBJECTS AND METHOD}

\section{Study Design}

This study used a cross sectional study conducted at 25 schools in Klaten, Central Java, in February 2020.

\section{Population and Sample}

In this study, the population studied was all female adolescents aged 15 to 19 years old in the Klaten area in February 2020. Sampling used was probability sampling tech- 
niques to select female adolescents and schools in the Klaten area. The subjects used were 200 subjects from 8 subjects in each level 2 unit (school).

\section{Study Variable}

The dependent variable is the incidence of anemia in adolescents. Independent variables include: knowledge, family economy, menstrual patterns, consumption of blood supplement, and nutritional status and level 2 is school.

\section{Operational Definition of Variables}

Anemia is a state of $\mathrm{Hb}$ in the blood of $<12$ $\mathrm{g} / \mathrm{dL}$ based on blood tests.

Knowledge is students' knowledge about the definition, symptoms, causes, effects, and ways to prevent anemia.

Family economy is the average amount of fixed and side income from the head of the household, mother and other members each month which is stated in Rupiah.

Menstrual pattern is the level of menstrual frequency measured based on the frequency of menstrual length and the number of times changing the pads in a day.

Blood supplement consumption is an effort to use blood supplement to fulfill the needs of young women during menstruation.

Nutritional status is the nutritional state of each respondent. The measurement scale in the independent variable uses a continous scale, because for the needs of data analysis it is converted into a dichotomous scale.

\section{Study Instrument}

The data collection techniques was with primary data and secondary data. Primary data were obtained using a questionnaire filled out by study subjects. Secondary data were obtained from the Karanganyar District Health Office in the form of postpartum data in Karanganyar Regency. The instruments used were the Easy Touch brand hemoglobinometer, body scale, microtoice and questionnaire.

\section{Data Analysis}

The univariate analysis was to see the frequency distribution and characteristics of the study subjects, while the bivariate analysis used the chi-square test and the calculation of the odds ratio (OR) with a 95\% confidence level (CI) to study the relationship between the incidence of anemia in adolescents with the independent variable. Multivariate analysis was done using logistic regression through a multilevel approach indicated by the Intra Class Correlation (ICC) value.

\section{Study Ethic}

Study ethics include informed consent, anonymity, confidentiality and ethical clearance. Ethical clearance in this study was carried out at Dr. Moewardi Hospital Surakarta and was declared ethical based on decree number 576/XII/HREC/2020.

\section{RESULTS}

\section{Univariate Analysis}

The subjects in this study were 200 adolescents. Univariate analysis included anemia, knowledge of adolescents, family income, menstrual patterns, iron consumption, adolescents' nutritional status, age, and class.

Table 1 showed the results of descriptive statistical tests on the variables that include the number of study subjects, the mean, standard deviation, minimum and maximum values for measuring the dependent variable and the independent variable on a continuous scale. The mean describes the mean value and the standard deviation (SD) describes the variation in the data. If the standard deviation (SD) value is smaller than the mean value, it indicates that the data is representative and can be used as a representation of the entire data. 
Dewayanti et al./ Ecological Effect of School on the Risk of Anemia

Table 1. Univariate analysis (continuous data) knowledge of adolescents, family income, nutritional status of adolescents, age, and class on anemia among adolescents

\begin{tabular}{lccccc}
\hline \multicolumn{1}{c}{ Characteristics } & N & Mean & SD & Min. & Max. \\
\hline Age (years old) & 200 & 17.13 & 0.78 & 16 & 18 \\
Class (10-12) & 200 & 11.13 & 0.78 & 10 & 12 \\
Hemoglobin (g/dL) & 200 & 12.10 & 0.96 & 10 & 14 \\
Knowledge & 200 & 66.96 & 14.18 & 20 & 95 \\
Family Income (Rupiah) & 200 & $2,090,500$ & 559,306 & $1,000,000$ & $5,500,000$ \\
BMI & 200 & 21.45 & 2.08 & 16 & 26 \\
\hline
\end{tabular}

Table 1 shows the measurement of anemia variable in adolescents has a mean= 12.10 and $\mathrm{SD}=0.96$, the lowest anemia variable value was 10 and the highest was 14. The knowledge variable of adolescents has a mean $=66.96$ and $\mathrm{SD}=14.18$ with the lowest knowledge value, which was 20 and the highest was 95. Family income variable has a mean $=\mathrm{Rp} 2,090,500$ and $\mathrm{SD}=\mathrm{Rp}$ $559,306,59$ with the lowest family income

Table 2. Univariate analysis (dichotomy data) of adolescents' knowledge, family income, menstrual patterns, iron consumption, adolescents' nutritional status, age, and class on anemia among adolescents

\begin{tabular}{|c|c|c|}
\hline Variable & $\mathbf{N}$ & $\%$ \\
\hline \multicolumn{3}{|l|}{ Anemia } \\
\hline Normal & 175 & 87.5 \\
\hline Anemia & 25 & 12.5 \\
\hline \multicolumn{3}{|l|}{ Knowledge } \\
\hline Poor & 28 & 14.0 \\
\hline Good & 172 & 86.0 \\
\hline \multicolumn{3}{|l|}{ Family Income } \\
\hline$<\mathrm{MW}(\operatorname{Rp} 1,947,821)$ & 28 & 14.0 \\
\hline 2MW (Rp 1,947,821) & 172 & 86.0 \\
\hline \multicolumn{3}{|l|}{ Menstrual Pattern } \\
\hline Normal & 161 & 80.5 \\
\hline Abnormal & 39 & 19.5 \\
\hline \multicolumn{3}{|l|}{ Iron tablet consumption } \\
\hline No & 14 & 7 \\
\hline Yes & 186 & 93.0 \\
\hline \multicolumn{3}{|l|}{ Nutritional Status } \\
\hline Normal & 177 & 88.5 \\
\hline Abnormal & 23 & 11.5 \\
\hline \multicolumn{3}{|l|}{ Students' Age } \\
\hline $15-16$ years old & 50 & 25 \\
\hline 17-18 years old & 150 & 75 \\
\hline \multicolumn{3}{|l|}{ Grade } \\
\hline Low (10) & 50 & 25 \\
\hline $\operatorname{High}(11,12)$ & 150 & 75 \\
\hline
\end{tabular}

was Rp. 1,000,000 and the highest was Rp. 5,500,000. The nutritional status variable of adolescents has a mean $=21.45$ and $\mathrm{SD}=$ 2.08 with the lowest value of 16 and the highest was 26. Adolescents have a mean= 17.13 and $\mathrm{SD}=0.78$, with the lowest age was 16 years old and the highest was 18 years old. Classes/grades (10 to 12 ) have a mean= 11.13 and $\mathrm{SD}=0.78$, with the lowest grade of 10 and the highest grade was 12. 
Table 2 showed that most of the study subjects who were not anemia were 175 subjects (87.5\%), 172 subjects had good knowledge (86.0\%), family income $\geq \mathrm{Rp}$ $1,947,821$ were 172 (86.0\%), normal menstrual were 161 (80.5\%), consumed iron tablet were 186 (93.0\%), and normal nutritional status were 177 (88.5\%). Most of the subjects were 17 to 18 years old, who were 150 students (75\%). And most of the students come from high grade (grade 11 and 12 ) by 150 students $(75 \%)$ and 50 students (25\%) come from grade 10.

\section{Bivariate Analysis}

The statistical analysis used to see the effect of a dependent variable (anemia) on the independent variable (adolescents' knowledge, family income, menstrual patterns, consumption of blood supplements, and nutritional status) in table 3 .

Table 3. Bivariate analysis of the effect of adolescents' knowledge, family income, menstrual patterns, blood supplement consumption, and adolescents' nutritional status on anemia among adolescents

\begin{tabular}{|c|c|c|c|c|c|c|}
\hline \multirow{3}{*}{ Independent Variable } & \multicolumn{4}{|c|}{ Anemia } & \multirow{3}{*}{ OR } & \multirow{3}{*}{$\mathbf{p}$} \\
\hline & \multicolumn{2}{|c|}{ Yes } & \multicolumn{2}{|c|}{ No } & & \\
\hline & $\mathbf{n}$ & $\%$ & $\mathbf{N}$ & $\%$ & & \\
\hline \multicolumn{7}{|l|}{ Knowledge } \\
\hline Poor & 10 & 35.71 & 18 & 64.29 & \multirow{2}{*}{5.81} & \multirow{2}{*}{$<0.001$} \\
\hline Good & 15 & 8.72 & 157 & 91.28 & & \\
\hline \multicolumn{7}{|l|}{ Family Income } \\
\hline$<\mathrm{MW}(\operatorname{Rp} 1,947,821)$ & 10 & $35 \cdot 71$ & 18 & 64.29 & \multirow[t]{2}{*}{5.81} & \multirow{2}{*}{$<0.001$} \\
\hline$\geq \mathrm{MW}(\operatorname{Rp} 1,947,821)$ & 15 & 8.72 & 157 & 91.28 & & \\
\hline \multicolumn{7}{|l|}{ Menstrual Pattern } \\
\hline Abnormal & 12 & 30.76 & 27 & 69.24 & \multirow[t]{3}{*}{5.06} & \multirow{2}{*}{$<0.001$} \\
\hline Normal & 13 & 8.07 & 148 & 91.93 & & \\
\hline \multicolumn{6}{|l|}{ Iron tablet consumption } & \\
\hline No & 7 & 50.00 & 7 & 50.00 & \multirow[t]{2}{*}{9.33} & \multirow{2}{*}{$<0.001$} \\
\hline Yes & 18 & 9.67 & 168 & 90.33 & & \\
\hline \multicolumn{7}{|l|}{ Nutritional Status } \\
\hline Abnormal & 9 & 39.13 & 14 & 60.87 & \multirow[t]{2}{*}{6.46} & \multirow[t]{2}{*}{$<0.001$} \\
\hline Normal & 16 & 9.03 & 161 & 90.97 & & \\
\hline
\end{tabular}

Table 3 shows the results of the chi-square test the effect of adolescent knowledge, family income, menstrual patterns, iron consumption, and adolescent nutritional status on anemia in adolescents as follows:

\section{a. The effect of adolescent know-} ledge on anemia in adolescents Good knowledge reduced the likelihood of anemia in adolescents. Adolescents with good knowledge decreased the likelihood of anemia by 5.81 times than adolescents with poor knowledge $(\mathrm{OR}=5.81, \mathrm{p}<0.001)$.

b. The effect of family income on anemia in adolescents

Family income $>\operatorname{Rp} 1,947,821$ reduce the likelihood of anemia in adolescents. Ado- lescents with a family income $>\mathrm{Rp}$ $1,947,821$ reduce the likelihood of anemia by 5.81 times than adolescents with family income $<$ Rp 1,947,821 (OR=5.81, $\mathrm{p}<0.001)$.

c. The effect of menstrual pattern on anemia in adolescents

Regular menstrual patterns reduce the likelihood of anemia in adolescents. Adolescents with regular menstrual patterns had a 5.06 times lower chance of anemia than adolescents with irregular menstrual patterns $(\mathrm{OR}=5.06, \mathrm{p}<0.001)$.

d. The effect of iron tablet consumption on anemia in adolescents

Adolescents who consume iron tablet reduce the likelihood of anemia. Adoles- 
cents who consumed iron tablet decreased the risk of anemia by 9.33 times than adolescents who did not consume blood supplement $(\mathrm{OR}=9.33, \mathrm{p}<0.001)$.

e. The effect of nutritional status on anemia in adolescents

Good nutritional status reduced the likelihood of anemia in adolescents. Adolescents with good nutritional status reduce the likelihood of anemia by 6.46 times than those with poor nutritional status $(\mathrm{OR}=$ $6.46, \mathrm{p}<0.001)$.

3. Multivariate Analysis with a Multilevel Analysis Approach

Multilevel multiple logistic regression analysis explained the effect of more than one independent variable and variable at level 2 , namely school. The results of the analysis can be seen in Table 4 .

Table 4. Multilevel multiple logistic regression analysis results of the influence of adolescent knowledge, family income, menstrual patterns, blood supplement consumption, and nutritional status of adolescents on anemia in adolescents

\begin{tabular}{|c|c|c|c|c|}
\hline \multirow[b]{2}{*}{ Independent Variables } & \multirow[b]{2}{*}{ (b) } & \multicolumn{2}{|c|}{$95 \% \mathrm{CI}$} & \multirow[b]{2}{*}{$\mathbf{p}$} \\
\hline & & $\begin{array}{c}\text { Lower } \\
\text { Limit }\end{array}$ & $\begin{array}{l}\text { Upper } \\
\text { Limit }\end{array}$ & \\
\hline \multicolumn{5}{|l|}{ Fixed Effect } \\
\hline Knowledge (good) & -2.29 & -4.23 & -0.32 & 0.022 \\
\hline Family income ( $\geq$ MW (Rp. 1,947,821) & -2.73 & -4.58 & -0.75 & 0.006 \\
\hline Menstrual pattern (regular) & -3.07 & -5.84 & -1.28 & 0.002 \\
\hline Blood supplement consumption (yes) & -3.22 & -8.96 & -2.17 & 0.001 \\
\hline Nutritional status (normal) & $-3 \cdot 36$ & -6.65 & -1.74 & 0.001 \\
\hline \multicolumn{5}{|l|}{ Random effect } \\
\hline School Variable & 4.80 & & & \\
\hline $\mathrm{N}$ observation $=200$ & & & & \\
\hline $\mathrm{N}$ group $=25$ & & & & \\
\hline Average group $=8, \min =8, \max =8$ & & & & \\
\hline Log likelihood= -41.38 & & & & \\
\hline$p=0.008$ & & & & \\
\hline $\begin{array}{l}\text { p LR test vs logistic regression }=0.002 \\
\mathrm{ICC}=59.36 \%\end{array}$ & & & & \\
\hline
\end{tabular}

Table 4 showed that knowledge, family economy, menstrual patterns, consumption of blood-supplemented tablets, and nutritional status have a statistically significant effect on the incidence of anemia in adolescents. The results of the logistic regression analysis can be described as follows:

\section{a. The effect of adolescent knowledge on anemia in adolescents}

There is a positive influence between adolescent knowledge on anemia in adolescents. Adolescents who have poor knowledge have the risk (logodd) of experiencing anemia by 2.29 units higher compared to adolescents who have good knowledge ( $\mathrm{b}=$ 2.29; $95 \% \mathrm{CI}=0.32$ to $4.23 ; \mathrm{p}=0.022$ ).

b. The effect of family income on anemia in adolescents

There is a positive influence between family income on anemia in adolescents. Adolescents who have an economy $<\operatorname{Rp} 1,947,821$ have a risk (logodd) of experiencing anemia by 2.73 units higher compared to adolescents who have a family income $\geq \mathrm{Rp}$ $1,947,821(b=2.73 ; 95 \% \mathrm{CI}=0.75$ to 4.58 ; $\mathrm{p}=0.006)$.

\section{c. The effect of menstrual pattern on anemia in adolescents}

There is a positive influence between menstrual patterns on anemia in adolescents. 
Adolescents who have abnormal menstrual patterns have a logodd risk of experiencing anemia by 2.29 units higher compared with adolescents who have normal menstrual patterns $(b=2.29 ; 95 \% \mathrm{CI}=0.75$ to $4.58 ; \mathrm{p}=$ o.001).

\section{d. The effect of blood supplement consumption on anemia in adolescents}

There is a positive influence between blood supplement consumption on anemia in adolescents. Adolescents who did not consume blood supplement had a risk (logodd) of anemia by 3.22 units higher compared to adolescents who consume iron tablet $(\mathrm{b}=$ $3.22 ; 95 \% \mathrm{CI}=2.17$ to $8.96 ; \mathrm{p}=0.001$ ).

\section{e. The effect of nutritional status on anemia in adolescents}

There is a positive influence between nutritional status on anemia in adolescents. Adolescents who have abnormal nutritional status have a logodd risk of experiencing anemia by 3.36 units higher compared to adolescents who have normal nutritional status $(b=3.36 ; 95 \% \mathrm{CI}=1.74$ TO 6.65; $\mathrm{p}=$ o.001).

\section{f. The effect of school on anemia in adolescents}

The school level shows that there is a contextual effect on anemia in adolescents (ICC $=59.36 \%$ ), this shows that the variation of postpartum depression is $59.36 \%$ determined by variables at the school level. The ICC value in this study is greater than the $8-10 \%$ rule of thumb, so the contextual influence, namely school, is very important.

\section{DISCUSSION}

1. The effect of adolescent knowledge on anemia in adolescents

Knowledge has a great influence on the occurrence of anemia in adolescents. Knowledge influences a person to take an action as well as to prevent or overcome anemia. Research by Kabir et al. (2010) showed that
$73.8 \%$ of the participants did not know about iron-rich food sources due to the lack of knowledge that adolescents have. So that teenagers are wrong in choosing food consumption.

In line with Chalise et al. (2018) who concluded that the level of education is one of the fundamental causes that can lead to anemia. This is because the level of education affects the level of knowledge on nutritional intake that must be fulfilled every day. A good understanding of adequate nutritional intake will have an impact on a good diet so that it can prevent anemia in the community, especially in adolescent girls who are prone to anemia. The majority of adolescents do not know about the symptoms of anemia, vitamins involved in iron, few teenagers know about iron-rich food sources, adolescents do not know about anemia prevention (Kamat and Sangupta, 2019).

A study by Pareek and Hafiz (2015) concluded that most of the subjects had wrong food habits, $60 \%$ of subjects ate out once a week and $23 \%$ of the subjects ate out twice a week. Most of them prefer to eat fast food and soft drinks. Only 25\% of the subjects have good knowledge about anemia. A person's knowledge can influence the occurrence of anemia, because knowledge can affect their behavior, including their lifestyle and eating habits. Lack of knowledge about anemia, its signs, effects, and prevention results in adolescents consuming foods that contain little iron so that the iron intake they need is not fulfilled.

\section{The effect of family income on anemia in adolescents}

There was a positive influence between family income on anemia in adolescents. Adolescents who have an economy $<\mathrm{Rp}$ $1,947,821$ have a risk (logodd) of experiencing anemia by 2.73 units higher compared to adolescents who have a family 
income $\geq \operatorname{Rp~} 1,947,821(b=-2.73 ; 95 \% \mathrm{CI}=-$ 4.58 to $-0.75 ; \mathrm{p}=0.006$ ).

Female adolescents who have parents with high incomes are easier to get all their needs, both primary and secondary needs, and with high incomes, parents can provide a variety of nutritious foods like their children, in contrast to adolescents who have low income parents, they must accept the food given by their parents because they cannot ask for more due to the limited income of their parents. The higher the income of the parents, the easier it is to get the facilities and infrastructure needed by the child, while the parents with a low economic background, it is more difficult for them to get the facilities and infrastructure needed by the child and the less time they can give to their children because of the parents prioritizing to fulfill daily needs (Kim et al., 2014; Jawarkar et al., 2015).

A study by Mangistu et al. (2019) concluded that the prevalence of anemia was found to be $11.1 \%$ with low economic status which can directly affect changes in family food consumption. Increased income means increasing opportunities to buy food of better quality and quantity. Conversely, a decrease in income will cause a decrease in the quality and quantity of food purchased, which can result in the body's need for nutrients not being fulfilled, one of which is not fulfilling the body's need for iron, which can lead to anemia.

Economic status can cause a person to have balanced eating habits, especially ironrich food groups. The low economic level (income) of the family will affect the pattern and type of family food, in which most of the families who have a low economic level (income) prefer carbohydrate-oriented foods to protein, vitamins and minerals. This is because foods containing carbohydrates are cheaper than others. Low economies tend to suffer from malnutrition. This will affect the ability to consume food and nutrients so that this situation leads to anemia in adolescents (Gonete et al., 2018; PAHO, 2010).

\section{The effect of menstrual pattern on anemia in adolescents}

The results of this study indicated that there was a positive influence between menstrual patterns on anemia in adolescents. Adolescents who had a normal menstrual pattern had a logodd risk of anemia by 2.29 units lower than adolescents with abnormal menstrual patterns $(b=-2.29$; $95 \% \mathrm{CI}=-4.58$ to $-0.75 ; \mathrm{p}=0.001)$.

The need for iron in female adolescent is higher than male adolescent, because it is needed to replace the iron lost during menstruation. One of the causes of nutritional anemia is chronic blood loss. In women, there is blood loss every month which happened naturally. If there is a lot of blood that comes out during menstruation, iron deficiency anemia will occur. Irregular menstruation for $\geq 5$ days were 2.4 times more likely to be anemic than adolescent girls with menstrual flow $<5$ days per each cycle (Mangistu et al., 2019; Ahmed et al., 2018).

Women will experience menstruation every month and will experience blood loss every month. Adolescents who have abnormal menstrual periods will experience more blood loss during menstruation than respondents who have normal menstrual periods. The length of the menstrual process will affect the number of red blood cells in the body, the longer the menstruation process, the more blood that comes out, which can cause anemia problems in women. In addition, menstrual patterns are also influenced by the personal hygiene of a teenager (PAHO, 2010; ACOG, 2015; Kunaryanti et al., 2019). 
Heavy regular and irregular cycles are important factors contributing to adolescent anemia. Heavy bleeding during menstruation in women has a negative impact. It can decrease iron levels and hemoglobin counts and cause anemia in women if not treated. Fatigue is a sign that women experience anemia due to bleeding during menstruation (Kocaoz et al., 2019; Toheed et al., 2017).

The impact of anemia on female adolescent is that during their growth period, they are prone to infection, decreased body fitness, decreased enthusiasm for learning and achievement, so that at times they will become prospective mothers with high risk conditions. If menstrual irregularities in adolescents last in a long time, they should immediately check with their doctor for therapy. Adolescents with a history of untreated anovulatory cycles for 2 years to 3 years should be evaluated with an endometrial biopsy, because there is an increased risk of endometrial carcinoma in these patients (Elmaogullari and Aycan, 2018).

\section{The effect of blood supplement consumption on anemia in adolescents}

The results of this study indicate that there is a positive influence between consumption of blood supplement on anemia in adolescents. Adolescents who consume blood supplement had a risk (logodd) of anemia by 3.22 units lower than adolescents who did not consume blood supplements $(b=-$ 3.22; $95 \% \mathrm{CI}=-8.96$ to $-2.17 ; \mathrm{p}=0.001$ ).

The use of blood supplements affects the incidence of anemia in adolescents. Fe deficiency anemia is prevented by maintaining a balance between $\mathrm{Fe}$ intake and $\mathrm{Fe}$ intake and loss. The amount of iron required to maintain this balance varies from woman to woman, depending on reproductive history and the amount of blood loss during menstruation. Increasing consumption of $\mathrm{Fe}$ to fulfill $\mathrm{Fe}$ needs is done through increasing consumption of foods containing heme iron and minimizing consumption of foods containing inhibiting factors for Fe absorption (Ramzi et al., 2011; Aprianti et al., 2018).

If the need for iron is not fulfilled from the diet, iron supplements can be added, especially for pregnant women and childbirth and adolescents who are in the process of growth. Fe supplementation is one of the strategies to increase Fe intake which is successful only if the individual adheres to the consumption rules. Another form of strategy used to increase compliance with $\mathrm{Fe}$ consumption is through education about the importance of Fe supplementation and the side effects of consuming Fe. Iron deficiency anemia occurs because the dietary pattern of Indonesian people is still dominated by vegetables as a source of iron that is difficult to absorb, while meats are good sources of iron for consumption in insufficient amounts (Mulugeta et al., 2015; Mahmudiono et al., 2019).

The low consumption of iron is also caused by the low ability of the family to provide a source of iron, especially animal protein in their daily diet, in addition, because the respondents' food consumption is still monotonous, the habit of consuming tea after eating also has an impact on low iron absorption in the respondent's body. For this reason, the role of local health workers is very important in socializing iron supplementation for young women, especially during menstruation, because iron is an essential microelement for the body, as the main factor in forming haemoglobin (Chalise et al., 2018). 


\section{The effect of nutritional status on anemia in adolescents}

The results of this study indicate that there was a positive influence between nutritional status on anemia in adolescents. Adolescents who have good nutritional status have a risk (logodd) for experiencing anemia by 3.36 units lower than adolescents who have abnormal nutritional status $(b=-3.36$; 95\% $\mathrm{CI}=-6.65$ to $-1.74 ; \mathrm{p}=0.001)$.

Gonete et al. (2018) who concluded that anemia is a public health problem that can occur in adolescent women. In adolescence, changes occur in a person's physical, biological, and psychological and occur continuously during adolescence. An imbalance between intake and nutritional needs results in nutritional problems, both under nutrition and over nutrition. Anemia is significantly associated with a low BMI for age. Female adolescents who have a low BMI for ages are 3.2 times more likely to be anemic than those who have a BMI for ages (Mangistu et al., 2019).

This is in line with Ahwal (2016) which concluded that a higher prevalence of anemia is among female adolescent. Iron intake and absorption which causes anemia in female adolescent. Basically, anemia is directly influenced by the daily consumption of foods that contain less iron, in addition to infection as the trigger. In general, food consumption is closely related to nutritional status. If the food consumed has a good nutritional value, the nutritional status is also good, on the other hand, if the food consumed is of less nutritional value, it will cause malnutrition and can cause anemia (Hapzah and Yulita, 2012).

Adolescents with high nutritional status can reduce the incidence of anemia. If the nutritional status is deficient, the incidence of anemia is high. Good nutrition will be achieved by providing balanced food for the body according to the needs and lack of nutrition illustrates the imbalance of the food eaten with the needs of the human body. The nutritional status of adolescents greatly affects the incidence of anemia. In adolescents the diet is not certain, especially in female adolescent who mostly have unhealthy diets in order to maintain an ideal body weight. In fact, an unhealthy diet can cause problems in nutritional status which greatly affect the incidence of anemia in adolescents. Health education about nutritional status is very influential on food consumption patterns in adolescents (Tesfaye et al., 2015; Ocak et al., 2017; Said et al., 2020).

\section{The effect of school on anemia in adolescents}

The results showed that there was a contextual influence at the school level indicating that there was a contextual effect on anemia in adolescents with scores (ICC= $59.36 \%$ ). The variation of anemia among adolescents was $59.36 \%$ influenced by school. The ICC value in this study is greater than the $8-10 \%$ rule of thumb, so the contextual influence in this study is that school is very important.

School is an institution for students teaching students under the supervision of the teacher. Most countries have formal education systems that are generally compulsory. In this system, students progress through a series of teaching and learning activities in schools. The names for these schools vary by country (discussed in the Regions section below), but generally include primary schools for young children and secondary schools for adolescents who have completed primary education.

Senior High School, is a form of formal education unit that provides general education at the secondary education level as a continuation of JHS, MTs, or other forms of equivalent or continuation of learning outcomes that are equal/ equiva- 
lent to JHS or MTs. Madrasah Aliyah, which abbreviated as MA, is a form of formal education unit under the guidance of the Minister of Religion which provides general education with the uniqueness of the Islamic religion at the secondary education level as a continuation of JHS, MTs, or other forms of equivalent or advanced learning outcomes that are recognized as the same or equivalent to JHSor MTs. Vocational High School, which abbreviated as VHS, is a form of formal education unit that provides vocational education at the secondary education level as a continuation of JHS, MTs, or other forms of equivalent or advanced learning outcomes that are recognized as equal or equivalent to JHS or MTs (Republic of Indonesia Government Regulation Number 66 of 2010).

Schools are one of the facilities that can help prevent anemia in adolescents by cooperating with health workers and schools. One of the ways that can be done is by conducting counseling and health education regarding anemia which includes danger signs and types of foods that contain iron. In addition, it is also possible to provide iron supplements to adolescents in school. Various studies have shown schoolbased iron and folic acid supplementation as a feasible and effective intervention to prevent hemoglobin reduction and reduce the prevalence of iron deficiency anemia in female adolescents (Mulugeta et al., 2015; Dharmalingam et al., 2017).

School programs by providing health education, health counseling, and providing iron supplements can be carried out since they are at the Junior High School/ Madrasah Tsanawiyah/equivalent level to detect or prevent anemia in adolescents. So that teenagers from an early age already have knowledge about anemia. Whether it's about the signs of anemia, the impact of anemia, and some foods that contain iron
(Mahmudiono et al., 2019; Regasa and Haidar 2019).

Based on the results of the study, it can be concluded that there is a significant influence between knowledge, family economy, menstrual patterns, consumption of blood supplements, and nutritional status with anemia in adolescents. Variations at the school level indicate a contextual influence on the incidence of anemia in adolescents.

AUTHOR CONTRIBUTION
Nurmala Dewayanti as the main has the
role in coordinating the study, conducting
all stages of the study, and completing the
study paper. Bhisma Murti has the role in
compiling the study framework, processing
study data, presenting the results of study
analysis, and preparing study papers.
Endang Sutisna Sulaeman has a role in
developing ideas, study designs, and study
hypotheses.

CONFLICT OF INTEREST

There was no conflict of interest in this study.

\section{FUNDING AND SPONSORSHIP}

The funding for this study used personal cost of the main researcher.

\section{ACKNOWLEDGEMENT}

Our gratitude goes to all school principals and high school teachers in Klaten Regency who has helped the study and students who have been willing to become study subjects.

\section{REFERENCE}

Ahmed AA, Yousef YE, Thabet AM, Alzahrain AE (2018). Impact of educational program on theimprovement of anemia due to menstrual disorder in adolescent girls. IOSR-JNHS, 7(3): 6o-66, https://doi:10.9790/1959-0703016066 
Ahwal S (2016). A study to assess the knowledge and prevalence of iron deficiency anemia among adolescent girls in a selected college of New Delhi. J Nurs Sci Pract. 6(3): 57-60. http://www.stmjournals.com/index.php?jou rnal $=$ JoNSP\&page $=$ article\&op $=$ view\& path $\% 5 \mathrm{~B} \% 5 \mathrm{D}=7239$.

Aprianti R, Sari GM, Kusumaningrum T (2018). Factors correlated with the intention of iron tablet consumption among female adolescents. Journal Ners, 13(1). http://dx.doi.org/10.20473/jn.v13i1.8368.

Badan Penelitian dan Pengembangan Kesehatan Departemen Kesehatan RI (2013). Riset Kesehatan Dasar (Basic Health Research). Jakarta

Briawan D (2013). Anemia masalah gizi pada remaja wanita (Anemia of nutritional problems in young women). Jakarta: EGC.

Chalise B, Aryal KK, Mehta RK, Dhimal M, Sapkota F, Mehata S, Karki KB, et al. (2018). Prevalence and correlates of anemia among adolescents in Nepal: Findings from a nationally representative cross-sectional survey. Plos One. 13(12): eo208878. https://doi.org/10.1371/journal.pone.0208878.

Dharmalingam A, Raghupaty NS, Mena R, Murali S (2017). Cross sectional study on nutritional status and prevalence of anemia in rural adolescents. Int $\mathrm{J}$ Contemp Pediatr. 4(3): 951-955. https://doi:10.18203/2349-3291.ijcp20171705.

Data Pokok Pendidikan (2020). Jumlah Satuan Pendidikan (Sekolah): Prov. Jawa Tengah (Number of Education Units (Schools): Central Java). Retrieved from https://siadik.pdkjateng.go.id/o300oo/sp_03.php.

Elmaogullari S, Aycan Z (2018). Abnormal uterine bleeding in adolescents. $\mathrm{J}$ Clin
Res Pediatr Endocrinol, 10(3): 191197, https://doi:10.4274/jcrpe.0014

Fakhidah LN, Putri KSE (2016). Faktorfaktor yang berhubungan dengan status hemoglobin pada remaja putri (Factors Associated with Hemoglobin Status in Female Adolescents). Jurnal Ilmiah Maternal, 1(1): 60-66. https://ejurnal.stikesmhk.ac.id/index.php/jurnal_ilmiah_maternal/article/vie $\mathrm{w} / 606$.

Gilly A (2009). Buku Ajar Kesehatan Reproduksi Wanita 2nd ed (Textbook of Women's Reproductive Health, 2nd ed). Jakarta: EGC.

Gonete KA, Tariku A, Wami SD, Derso T (2018). Prevalence and associated factors of anemia among adolescent girls attending high schools in Dembia District, Northwest Ethiopia, 2017. Arch Public Health, 76(79), https://doi.org/10.1186/s13690-018-0324-y.

Hapzah, Yulita R (2012). Hubungan tingkat pengetahuan dan status gizi terhadap kejadian anemia remaja putri pada siswi kelas III Di SMAN 1 Tinambung Kabupaten Polewali Mandar (relationship of knowledge level and nutritional status on the incidence of anemia in female adolescent in class III at SMAN 1 Tinambung, Polewali Mandar Regency). Media Gizi Pangan, 12, Retrieved from https://jurnalmediagizipangan.files.wordpress.com/2012/o7/hubungan-tingkat-pengetahuandan-status-gizi-terhadap-kejadiananemia-remaja-putri.pdf

Jawarkar AK, Lokare PO, Kizhatil A, Jawarkar JA (2015). Prevalence of anemia and effectiveness of iron supplementation in anemic adolescent school girls at Amravati City (Maharashtra), J Health Res Rev, 2(1): 7-10, https://doi:10.4103/2394-2010.158122. 
Kabir Y, Shahjalal HM, Saleh F, Obaid W (2010). Dietary pattern, nutritional status, anaemia and anaemia-related knowledge in urban adolescent college girls of Bangladesh. J Pak Med Assoc, 60(8): 633-8. Retrieved from https://www.ncbi.nlm.nih.gov/pubmed/20726192.

Kamat S, Sengupta R (2019). Nutrition intervention for improvement of knowledge on anaemia prevention among adolescent girls in Mumbai (16- 19 Years). IJNFS, 4(2): 136-139, https://www.foodsciencejournal.com

Kim JY, Shin S, Han K, Lee KC, Kim JH, Choi YS, Kim DH, et al. (2014). Relationship between socioeconomic status and anemia prevalence in adolescent girls based on the fourth and fifth Korea National Health and Nutrition Examination Surveys. Eur J Clin Nutr, 68(2): 253-8, https://doi.org/10.1038/ejcn.2013.241.

Kocaoz S, Cirpan R, Degirmencioglu AZ (2019). The prevalence and impacts heavy menstrual bleeding on anemia, fatigue and quality of life in women of reproductive age. Pak J Med Sci, 35(2): 365-370, https://doi:10.12669/pjms.35.2.644.

Mahmudiono T, Setyaningtyas SW, Ridlo IA, Rachmah Q, Nindya TS (2019). Consumption of iron supplement and anemia among Indonesian Adolescent Girls. Global J Health Sci, 11(2), https://doi:10.5539/gjhs.v11n2p64

Mangistu G, Azage M, Gutema H (2019). Iron deficiency anemia among inschool adolescent girls in rural area of Bahir Dar City Administration, North West Ethiopia. Hindawi, 2019: 1-8 https://doi.org/10.1155/2019/1097547

Mulugeta A, Tessema M, Hsellasie K, Seid O, Kidane G, Kebede A (2015). Exami- ning Means of Reaching Adolescent Girls for Iron Supplementation in Tigray, Northern Ethiopia. Nutrients, 7(11): 9033-9045, https://doi:10.3390/nu7115449

Ocak S, Kilicaslan O, Yildiz Z, Yildirmak, Urganc $N$ (2017). Adolescents and Anemia. The Medical Bulletin of Sisli Etfal Hospital, 51(4), https://doi:10.5350/SEMB.20170927094446.

Pan American Health Organization (2010). Anemia among adolescent and young adult women in Latin America and The Caribbean: A Cause for Concern. Retrieved from http://www.paho.org/hq/dmdocuments/2010/AnemiaEng WEB.pdf.

Pareek P, Hafiz A (2015). A study on anemia related knowledge among adolescent girls. Int J Nutr Food Sci. 3: 273276. https://doi:10.11648/j.ijnfs.20150403.14.

Pemerintah Kabupaten Klaten (2019). Mengkampanyekan waspada anemia di atas goresan pesan poster (Campaigning of Anemia Above Poster Message Scratches). Retrieved from https://klatenkab.go.id/mengkampanyekan-waspada-anemia-di-atasgoresan-pesan-poster/.

Peraturan Pemerintah Republik Indonesia. Nomor 66 Tahun 2010. Pengelolaan dan penyelenggaraan pendidikan (Management and Implementation of Education). Retrieved from http://luk.staff.ugm.ac.id/atur/PP17-2010Lengkap.pdf.

Ramzi M, Haghpanah S, Malekmakan L, Cohan N, Baseri A, Alamdari A, Zare N (2011). Anemia and Iron Deficiency in Adolescent School Girls in Kavar Urban Area, Southern Iran. Iran Red Crescent Med J, 13(2): 128-133, https://www.ncbi.nlm.nih.gov/pmc/a rticles/PMC3371916/. 
Regasa RT, Haidar JA (2019). Anemia and its determinant of in-school adolescent girls from rural Ethiopia: A school based cross-sectional study. BMC Women's Health, 19(98), https://doi.org/10.1186/s12905-019-0791-5

Simamora D, Kartasurya MI, Pradigdo SF (2018). Hubungan asupan energi, makro dan mikronutrien dengan tekanan darah pada lanjut usia (Relationship of energy intake, macro and micronutrients with blood pressure in the elderly). Jurnal Kesehatan Masyarakat, 6(1): 426-435. Retrieved from https://ejournal3.undip.ac.id/index.$\mathrm{php} / \mathrm{jkm} /$ article/view/19902.

Suryani D, Hafiani R, Junita R (2015). Analisis pola makan dan anemia gizi besi pada remaja putri Kota Bengkulu (Analysis of diet and iron nutrient anemia in young women in Bengkulu City). Jurnal Kesehatan masyarakat Andalas, 10(1): 11- 18. Retrieved from http://jurnal.fkm.unand.ac.id/index.$\mathrm{php} / \mathrm{jkma} /$ article/view/157

Tesfaye M, Yemane T, Adisu W, Asres Y, Gedefaw L (2015). Anemia and iron deficiency among school adolescents: burden, severity, and determinant factors in Southwest Ethiopia. Adolesc Health Med Ther, 6: 189-196. https://doi:10.2147/AHMT.S94865

The American Collage of Obstetricians and Gynecologists (2015). Menstruation in girls and adolescents: Using the menstrual cycle as a vital sign. Pediatrics. doi: 10.1542/peds.2006-2481

Toheed R, Ayub TB, Ali HS, Ali F (2017). Prevalence of menstrual dysfunction and its comparative correlation with anaemia. Journal of Rawalpindi Medical College. 21(2): 157-160. Retrieved from https://journalrmc.com/volumes/12_Prevalence\%20of\%2oMe nstrual\%20Dysfunction\%20and\%20it s\%20Comparative\%2oCorrelation\%2 owith\%2oAnaemia.pdf. 